\title{
EVALUATING CROWDFUNDING FROM THE PERSPECTIVE OF PUBLIC RELATIONS
}

\author{
Murat SEYFI \\ Gaziosmanpaşa University, School of Applied Science, Turkey \\ seyfi.murat@gmail.com \\ Ayda Uzunçarşı1l SOYDAŞ \\ Marmara University, Communication Faculty, Turkey \\ Deniz GÜVEN \\ Marmara University, Communication Faculty, Turkey
}

\begin{abstract}
Developments in communication technologies caused both the development of practices of public relations and emergence of new practice areas. Now, public relations can reach the individuals from various different aspects and can transfer private messages to the individuals with use of new technologies. Thus, transferring messages to the audience and creating a behavioural change on the audience, which are the bases of public relations, have acquired a new dimension. For this reason, professionals of public relations are creating practice areas in new digital-based communication platforms. Crowdfunding web pages, whose popularity has been increasing each passing day in the recent years, have become an important platform of transfer of messages, and have started to be used frequently by both the individuals and the professionals of public relations. This study researches how crowdfunding web pages can be used as a means of public relations and makes suggestions on the use of crowdfunding as a means of public relations as a result of the literature and netnographic research on the topic.
\end{abstract}

Keywords: Crowdfunding, Public Relations, Communication

\section{HALKLA İLIŞKILLR PERSPEKTİFINDE KITLESEL FONLAMANIN DEĞERLENDİILMESI}

\section{ÖZ}

İletişim teknolojilerindeki gelişmeler hem halkla ilişkiler uygulamalarının gelişmesine hem de yeni uygulama alanlarının ortaya çıkmasına sebep olmuştur. Artık halkla ilişkiler yeni teknolojilerin kullanımı ile bireye çok farklı açılardan ulaşabilmekte ve bireye özel mesaj aktarımı yapılabilmektedir. Böylelikle halkla ilişkilerin temelini oluşturan hedef kitleye mesaj aktarma ve hedef kitlede davranış değişikliği yaratma süreci yep yeni bir boyut kazanmıştır. Bu yüzden de halkla ilişkiler profesyonelleri dijital temelli yeni iletişim platformlarında uygulama alanları yaratmaktadırlar. Son yıllarda her geçen gün popüleritesi artan kitlesel fonlama web sayfaları da önemli bir mesaj aktarma platformuna dönüşmüş olup, hem bireyler hem de halkla ilişkiler profesyonelleri tarafindan oldukça sık kullanılmaya başlanmıştır. Bu çalışmada kitlesel fonlama web sayfalarının nasıl halkla ilişkiler aracı olarak kullanılacağı araştırılmış olup, konu hakkında yapılan literatür ve netnografik araştırma sonucunda kitlesel fonlamanın bir halkla ilişkiler aracı olarak kullanılmasına yönelik öneriler geliştirilmiştir.

Anahtar Kelimeler: Kitlesel Fonlama, Halkla İlişkiler, İletişim

\section{INTRODUCTION}

People have started to live under a bombardment of messages due to globalisation and developments in communication technologies. Thus, received messages have become imperceptible and unanswerable for the people. Accordingly, professionals of public relations have started to develop new strategies in the process of reaching the audience. Now, practices of public relations have moved beyond of only advertising or analysing feedbacks from the audience and have become a multifactorial 
organic structure. Therefore, professionals of public relations have focused on communication studies on the internet platform where information spreads quickly and reaches to large crowds.

Due to both developments in communication technologies and development and constant changes in tendencies of people, new applications constantly appear in virtual platforms. While some of these applications fail, some of them reach great success. The popularity of on-line crowdfunding applications which appeared in 2000s has increased each passing day, and now they are among the most sought after applications in the world. This application, which was used by young entrepreneurs as a source of funding in the early times, started to be used in many fields such as art, charity and sport activities over the time. Thus, crowdfunding beyond being a simple search of funding, has become a strategic communication method. There have been many studies which aim to explain the factors affecting the success of campaigns of crowdfunding. This study differs from other studies in that it researches flow of communication by using netnography method. The aim of this study is to determine for which dimension of public relations the crowdfunding can be used by making use of a different research method, and to develop suggestions which are applicable to both corporate and individual marketing.

\section{THE CONCEPT OF PUBLIC RELATIONS}

There have been acts of public relations throughout the history of humankind; however, description studies of the concept from the aspect of both theory and practice started in the beginning of the 20 . century (Cutlip, 2013). There have been many studies intended to describe public relations and to determine its dimensions since beginning of the 20. century. Factors like social changes, technological factors and globalisation played an important role at the basis of the non-complete description of the concept. In particular, corporations' extending to wide areas and developing communication strategies for their activities forced the pace of the change of public relations into a profession. With public relation's centering on both corporate and social life each passing day, criticism and applications regarding the issue have increased day by day. For this reason, new concepts are being included in public relations each passing day, and the border of the concept of public relations widens and assumes important responsibilities. Because, while public relations manages the present time, it builds up the future (Peltekoğlu, 2015:1). Within this framework, corporations which are included in social and economic life as a dynamic structure, need effective communication inside and the outside of the corporation in order to realise their unique functions (Güven, 2016a: 135)

In his article studying description of public relations Hutton (1999) defines the concept of public relations based on 472 different descriptions of public relations by Harlow as:

"Public relations is a distinctive management function which helps establish and maintain mutual

lines of communication, understanding, acceptance and co-operation. Definition, Dimensions, and

Domain operation between an organization and its publics; involves the management of problems or issues; helps management to keep informed on and responsive to public opinion; defines and emphasizes the responsibility of management to serve the public interest; helps management keep abreast of and effectively utilize change, serving as an early warning system to help anticipate trends; and uses research and sound and ethical communication techniques as its principal tools."

Professionals of the occupation always maintained their studies on description of the concept even under the effects of rapid industrialisation in the beginning of the 20. century and increasing globalisation in the 70s (Long \& Hazelton, 1987). With 21. century, the concept acquired a new dimension with the technological developments, and needed new description studies. With 21. century, the concept has been under the effect of digitalisation and all the applications have gone into the process of digitalisation. Therefore, public relations can be defined as an organic communication chain which has horizontal and vertical components.

\section{Digitalisation of Public Relations}

The basis for the digitalisation of public relations is the digitalisation of communication. Any kind of information such as audio, picture and photograph has been digitalised with digital communication 
technologies (Lee, 2012: 2). While innovations in communication technologies and development in means of transportation have an important effect in digitalisation of communication especially in the second half of the 20. century, developments in question brought about creation of new relationship types and networks (Güven, 2016b: 91). Digitalisation of communication enables the topic to be analysed by both the digital sciences and social sciences; and thus the concept have become an interdisciplinary study field.

From the aspect of the communication sciences, the most important point in transition to digital communication is messaging of the devices. McLuhan (1964) gave a new perspective to the topic by saying The Device is The Message. McLuhan asserts that new communication technology creates a new life space and that flow of everything changes in this life space. That is to say, communication technologies constitute every layer of the life in schools, work places, homes, and it becomes impossible to interfere with them. In other words, technological elements plays a pivotal role in embodiment of cultural system, and constrain us in their own world. In addition, our messages somehow have started to be digitalised with digitalisation of devices. Now, our messages have started to reach to the opposite side with the pattern of digitalisation beyond our emotions. Communication and digitalisation have become such a structure which maintain themselves that messaging started to get lost within the digitalisation from time to time.

Another effect of developments in communications technologies is that current communication devices have ceased to be a device of transferring messages and have become a source of message (Seyfi \& Güven, 2016: 278). Furthermore, new life spaces have been created and social sharings, grouping, perceiving others have occurred in various fashions with the digitalisation of communication (Seyfi \& Soydaş, 2016). In communication chain used via digital games, learning models based on classical and performative habits, and behavioural, affective and cognitive learning approaches have important effects on users (Kuşay\&Akbayır, 2015: 152). As a result of the intense effects of digitalisation on communication and society, public relations studies on digital platforms have been affected directly. In particular, new media's being based on digital communication has brought about the obligation of putting forward a new perspective about the topic. Because, while traditional mass communication devices consider the audience as individuals without an identity, new technologies reaches to the individuals and transfers massages especially for an individual. Thus, transferring messages to the audience and creating a behavioural change on the audience, which are the bases of public relations, have acquired a new dimension.

Developments in communication technologies have widened the audience. Professionals of public relations have started to use web-based applications frequently in order to reach a wider target audience. With public relations applications conducted on internet platforms, messages have become creative, quick and result-oriented. Moreover, popularity of web-based public relations applications have been increasing each passing day. (Porter et al., 2007; Anderson \& Regan, 1992; Springston, 2001). There are four elements underlying this increase in popularity of public relations in digital platforms. These are that they are strategic, integrated, targeted and measurable (Holtz, 2002:16).

As a result of professionals of public relations' using web-based applications intensely, many dimensions of public relations have become digitalised by being moved to online platforms. Within this framework, the mostly used dimensions of public relations in digital platforms are as follows (Pelenk \& Y1lmaz, 2015);

- Online News Bulletins

- Search Engine Optimisation

- Corporate Blogs

- Corporate Web Design

- Social Media Management

- Relations with Online Communities

- Online Crisis Management

- Online Dignity Management 
Professionals of public relations tend to use every new popular communication platform as a means of public relations in order to make use of the advantages of digital communication. Within this framework, crowdfunding web pages whose popularity has been increasing in the recent years are being used as a means of public relations by both the individuals and corporations.

\section{CROWDFUNDING}

Crowdfunding is a new concept for entrepreneurs, business world, non-governmental organisations and individuals, and is a preferred platform to advertise the campaigns as successful and to fund the campaigns (Gerber, 2011; Muller et al., 2013; Vismara, 2016). Crowdfunding is a method of funding that provides fund to an enterprise or a project suggested on the internet with the joint effort of friends, family and individual enterprisers (Belleflamme et al., 2014). The most important feature of crowdfunding is that it produces a cheap and fast alternative for individuals who cannot reach traditional funding devices (Gerber \& Hui, 2013: 2). Beyond being a simple search for funding, crowdfunding is a successful platform in terms of enabling conventional flow of information. Therefore, crowdfunding web pages have social content activities like fund-raising as well as simple raising of funds; and thus they can do miscellaneous advertising activities by getting in touch with other social media devices. This creates a new social network regarding the topic. Comments, likes and sharings of this social network can be considered as a new source of information ( $\mathrm{Lu}$ et al., 2014: 574-578). Consequently, crowdfunding is not just a search for funding; it can also be considered as a strategic communication method.

Crowdfunding web pages have been growing each passing day. From 2009 up to now, in kickstarter, one of the most important representative of the sector, 12 million people have backed a Project , 2,8 billion dollar has been pledged, and 118.560 projects have been successfully funded (www.kickstarter.com).President Obama raised a fund of more than 500 million dollars with his crowdfunding works on online platforms in 2008 (http://www.crowd101.com). Even if online crowdfunding web pages sprung in America, they have gained popularity all around the world. In 2011, considering all types of crowdfunding, Europe raised around more than $€ 300$ million, one third of the world market, through hundreds of thousands of crowdfunding campaigns. For 2012, the estimate is that $€ 2.2$ billion will be raised globally by crowdfunding platforms, up $80 \%$ from $€ 1.2$ billion in 2011 and $€ 400$ million in 2009 (De Buysere et al., 2012: 22).

\section{Related Works}

With crowdfunding's reaching such a big market, the number of researches conducted about the topic has increased. When the studies about the topic are analysed, it can be seen that they generally focus on participant behaviours and factors affecting the success of funding. The studies conducted within this context can be summarised as follows:

Analysis studies aimed to determine how updates about the campaign affect the result of the campaign in the process of campaign (Xu et al., 2014); qualitative studies aimed to search effects of internal social capital on the campaign (Colombo et al., 2015); researches aimed to determine the effects of the creator of the campaign on the campaign (Wojciechowski, 2009); the effects of individual and aggregate studies on the campaign (Hui et al., 2014); studies aimed to determine the effects of social media on crowdfunding ( $\mathrm{Lu}$ et al., 2014). It can be seen that the studies generally focus on searching success and effect level of the campaign when these studies are analysed.

The number of studies in which crowdfunding is seen as a corporate communication device is limited. The first person to search crowdfunding from the perspective of marketing is Macht. According to Macht, provision of funds can be considered as the beginning of a long-term relationship between funders and fund-seekers, which would bring fund-seekers value-added benefits after the crowdfunding projects (Match, 2014). Wang, in his master's degree paper whose title is "corporate crowdfunding as a marketing communication tool" studied the effects of corporate crowdfunding on marketing (Wang, 2016). In another study searching the relationship between crowdfunding and 
communication, it is determined that communication studies play an important role for the sustainability of crowdfunding (Alfiero et al., 2014).

\section{METHODOLOGY}

The purpose of this study is to analyse how crowdfunding web pages are used as a means of public relations and to determine strategies accordingly. Within this context, methods of netnography and content analysis are used. Netnograpy is a natural, participatory, complementary, applicable research model which is from the new generation and has many methods (Varnal1, 2012;37). The basis for netnography is adapting the ethnography, which is used by anthropologists, to the internet. Netnography identifies online communities and analyses behaviours of these communities which they show during communication flow, events and objects. The important thing in netnography is multi-dimensional analysis of effects of online platforms on human behaviour (Kozinets, 2002). Since the method of netnography has the perspective of ethnography, it focuses on rituals, symbols and values which are the elements of being a community. Since virtual communities occurred in online platforms are more flexible and dynamic than traditional communities that are known by everyone, they have different dynamics. Beyond values and symbols, communication flow which will reveal different dynamics will be evaluated from the perspective of ethnography in this study.

Within this framework, the research questions are as follows:

RQ1: Is crowdfunding a means of public relations?

RQ2: Which of the dimensions of interpersonal communication does method of dignity that is a subdimension of crowdfunding and public relations use?

RQ3: At what rate are social media devices used in the process of crowdfunding?

RQ4: Does communication between campaign owners and supporters happen within the perspective of public relations?

\section{Research Findings}

Our study is conducted on communities created by participants of campaigns conducted on the web page of www.kickstarter.com which is one of the most popular online web pages. Within the context of the study, four random campaigns are analysed.

Kickstarter is an online crowdfunding page which was established in 2009. Data of their studies conducted until now can be summarised as:

\begin{tabular}{|l|l|l|l|l|l|l|l|}
\hline Category & $\begin{array}{l}\text { Launched } \\
\text { Projects }\end{array}$ & $\begin{array}{l}\text { Total } \\
\text { Dollars }\end{array}$ & $\begin{array}{l}\text { Successful } \\
\text { Dollars }\end{array}$ & $\begin{array}{l}\text { Unsuccessful } \\
\text { Dollars }\end{array}$ & $\begin{array}{l}\text { Live } \\
\text { Dollars }\end{array}$ & $\begin{array}{l}\text { Live } \\
\text { Projects }\end{array}$ & $\begin{array}{l}\text { Success } \\
\text { Rate }\end{array}$ \\
\hline All & 335.774 & $2.84 \mathrm{~B}$ & $2.49 \mathrm{~B}$ & $327 \mathrm{M}$ & $19 \mathrm{M}$ & 4.054 & $\% 35.75$ \\
\hline
\end{tabular}

Table 1: Statistics of crowdfunding of Kickstarter.com

Distribution of conducted projects according to categories;

\begin{tabular}{|c|r|r|r|l|r|r|}
\hline Category & $\begin{array}{l}\text { Launched } \\
\text { Projects }\end{array}$ & Total Dollars & $\begin{array}{l}\text { Successful } \\
\text { Dollars }\end{array}$ & $\begin{array}{l}\text { Unsuccessful } \\
\text { Dollars }\end{array}$ & $\begin{array}{l}\text { Live } \\
\text { Dollars }\end{array}$ & $\begin{array}{l}\text { Live } \\
\text { Projects }\end{array}$ \\
\hline Games & 28.959 & $\$ 589.66 \mathrm{M}$ & $\begin{array}{r}532.69 \\
\mathrm{M}\end{array}$ & $52.72 \mathrm{M}$ & $4.25 \mathrm{M}$ & 453 \\
\hline Design & 24.696 & $572.09 \mathrm{M}$ & $\begin{array}{r}512.74 \\
\mathrm{M}\end{array}$ & $55.20 \mathrm{M}$ & $4.14 \mathrm{M}$ & 534 \\
\hline Technolog & 27.291 & $560.61 \mathrm{M}$ & $\begin{array}{r}480.81 \\
\mathrm{M}\end{array}$ & $74.30 \mathrm{M}$ & $5.50 \mathrm{M}$ & 414 \\
\hline y & 59.932 & $361.91 \mathrm{M}$ & $\begin{array}{r}303.31 \\
\mathrm{M}\end{array}$ & $57.06 \mathrm{M}$ & $1.54 \mathrm{M}$ & 460 \\
\hline Video \& & 49.936 & $187.06 \mathrm{M}$ & 170.55 & $15.78 \mathrm{M}$ & $\$ 736.63$ & \\
\hline Music & & & & & & \\
\hline
\end{tabular}




\begin{tabular}{|c|c|c|c|c|c|c|}
\hline & & & M & & K & \\
\hline Publishing & 35.41 & $109.45 \mathrm{M}$ & $93.96 \mathrm{M}$ & $14.70 \mathrm{M}$ & $\begin{array}{r}\$ 788.08 \\
\mathrm{~K}\end{array}$ & 418 \\
\hline Food & 21.763 & $108.40 \mathrm{M}$ & $90.49 \mathrm{M}$ & $17.43 \mathrm{M}$ & $\begin{array}{r}\$ 484.40 \\
\mathrm{~K}\end{array}$ & 260 \\
\hline Fashion & 18.946 & $106.40 \mathrm{M}$ & $92.40 \mathrm{M}$ & $13.40 \mathrm{M}$ & $\begin{array}{r}\$ 603.18 \\
\mathrm{~K}\end{array}$ & 272 \\
\hline Art & 24.7 & $76.06 \mathrm{M}$ & $66.71 \mathrm{M}$ & $9.08 \mathrm{M}$ & $\begin{array}{r}\$ 276.05 \\
\mathrm{~K}\end{array}$ & 318 \\
\hline Comics & 8.976 & $59.98 \mathrm{M}$ & $55.45 \mathrm{M}$ & $4.23 \mathrm{M}$ & $\begin{array}{r}\$ 295.94 \\
\mathrm{~K}\end{array}$ & 129 \\
\hline Theater & 10.125 & $40.50 \mathrm{M}$ & $36.16 \mathrm{M}$ & $4.29 \mathrm{M}$ & $\$ 47,876$ & 60 \\
\hline $\begin{array}{l}\text { Photograp } \\
\text { hy }\end{array}$ & 9.904 & $31.74 \mathrm{M}$ & $27.42 \mathrm{M}$ & $4.16 \mathrm{M}$ & $\begin{array}{r}\$ 158.81 \\
\mathrm{~K}\end{array}$ & 89 \\
\hline Dance & 3.442 & $11.81 \mathrm{M}$ & $10.97 \mathrm{M}$ & $\$ 776.50 \mathrm{~K}$ & $\$ 58,426$ & 27 \\
\hline Crafts & 7.459 & $11.63 \mathrm{M}$ & $9.64 \mathrm{M}$ & $1.91 \mathrm{M}$ & $\$ 71,069$ & 159 \\
\hline $\mathrm{m}^{\text {Journalis }}$ & 4.235 & $10.77 \mathrm{M}$ & $9.04 \mathrm{M}$ & $1.65 \mathrm{M}$ & $\$ 73,732$ & 59 \\
\hline
\end{tabular}

Table2: Distribution of crowdfunding statistics of Kickstarter.com according to categories

When the campaigns conducted on kickstarter.com are examined, it can be seen that they are in 15 different categories, and communities created on this web page have different expectations and searches. It is remarkable that communities who have such different tendencies are in touch with each other on the same web page. This reveals the range of language and behavioural norms in online crowdfunding.

\section{Member Types:}

Corporate: Corporate entities, who are profit-oriented and non-profit corporations, seek support for their campaign on the web page.

Groups: Owners of the projects offered by friend groups who are formed by various friends or other friend groups who involve in charity activities.

Owners of Individual Campaign: Individuals who seeks funds for their own projects individually.

Supporters: People who examine projects, comment on them, and provide financial support for them on the web page.

These four clusters show a dynamic existence process. This dynamic existence process means that a person who is in the group of supporters can quickly be included in project offerors and vice versa. This transitivity among the member types also affects their way of communication.

When the demographic features and communication skills of member types are analysed netnographically, it can be seen that many factors have emerged in the analysis of this virtual community. Primarily, due to the fact that people from all around the world come together and act supportively for each other, factors regarding cross-cultural communication have emerged. On the other hand, a communication that is focused intensely on discussion or sharing among the member types on this web page is observed. Generally, members tend to visit other social media pages or visit outer places where the campaign takes place in order to engage in more communication. Therefore, communication among member types takes shape in relation to both the content of the campaign and the communication skills of the campaign manager. 
Content Analysis of Campaigns from the Perspective of Public Relations:

Campaign1: Accordion Play House-The Best Playhouse for Small Space

This campaign is supported by 79 participant from 9 countries in 10 days.

Owner of the Campaign:

The owner of the campaign first talks about himself and then about his story.

The brand "Cretoy" is a combination of Creative and Toy to reflect its being a creative and fun product. A creative product means that the product does not function in the same way for everyone but is instead something that changes, develops, and is re-created by users. Cretoy won the IDEA 2014 Gold Award for the Accordion Play House.

This is our first project on Kickstarter, but our team has experience in design and product manufacturing. The Accordion Playhouse is a brand new product, so timely shipping worldwide will be the main obstacle for us. We will do our best in delivering the product on time. However, there is always a chance that the manufacturing process could be delayed. We kindly ask for your patience and promise to fulfil your order as soon as possible without sacrificing quality.

Communication is the main key for us.

Thank you in advance for your support to Cretoy Accordion Play House.

The owner of the campaign mentions about the prize that will grant him a reputation in the paper introducing him.

The Communication between the Supporter Group and Owner of the Campaign:

Supporter: Very unique idea. Does the playhouse have a floor? Why is the flag element a separate cost? What are the dimensions of the door? Is there a way to attach things to the walls (like pictures)? I'm sure a child will want to hang things from the roof - is there a way to do so?

The Owner of the Campaign: Tea Speaks Thanks, That's a good question. There is no a floor. The flag is not a necessary element. The size of the circle is $20 \mathrm{inch}(500 \mathrm{~mm})$ in diameter. And the door has an elastic band so you can hang a doll. Ceilings and walls can be tied with clips. There are ten eyelets on the front and back plates and one on the door. It can be used to make flags or anything else.

Evaluation of the Communication: While the owner does not care about answering messages coming from the supporters, he acts sensitive and solution-oriented for the criticism and suggestions.

\section{Campaign2: HoneyComb: The Must Fun Electronic Block}

This campaign is supported by 72 supporters in 52 days, and 21,017 dollars is raised. The owner of the campaign aimed to raise 20,000 dollars and he easily overreached his aim.

The Owner of the Campaign:

We spent the last 12 months creating the next generation of electronic blocks, try integrate as cool technology as mind control, speech control, gesture recognition control to HoneyComb. No electronic experience, no coding, and no screens required, jut connect and play your creative. At beginning we launched our first 3 kits:

- Music Kit - Change anything into an instrument.

- Camera Kit - Create your own camera for multi-usage.

- IoT Kit - Drag the blocks to learn programming

Evaluation of the Communication: Between supporters and the owner of the campaign, there is generally supportive messages and an information exchange regarding the campaign. However, one message is completely out of the context of the campaign. This message coming from a different aspect proves that the flow of communication is not well-established.

Supporter: Hi there, I have launched my first project on Kickstarter. Could you please support or share in your network?

Kids toy to motivate walking and stay fit

https://www.kickstarter.com/projects/650005707/wheelo-play-unlimited

Any suggestion most welcome.

Campaign 3: Growing in the City: The Mountair Park Community Farm

This campaign is supported by 262 people and a total of 12,958 dollars is raised. 
The Owner of the Campaign: Sprout City Farms is about to break ground on the Mountair Park Community Farm in Lakewood, Colorado. We have been cultivating a one-acre farm at the Denver Green School since 2011, and are ready to replicate our model for sustainable urban food production and community resource building in another neighbourhood! This is the next big step in realizing our vision of creating a network of urban farms to support the Denver-metro area.... A large group of community members is helping guide development of the Mountair Park Community Farm and its programs. Possible food access efforts include farm to cafeteria programs for nearby schools, a donation-based farm stand, free and work shares in the CSA program, and donations to hunger relief organizations. Proposed educational opportunities include programs for local schools, community workshops, and an internship program. The possibilities are endless, but to make all of these community benefit programs a reality, we first have to build the farm!

Evaluation of the Communication: The owner of the campaign keep the communication live and transferred communication into different channels by making updates in the course of time; thank you so much for your support to get Mountair Park Community Farm started! Here's more on what we've been up to, and scroll down to the bottom for a special update on our expansion-we're now working on Farm \#3 here in Denver!

The owner of the campaign showed tendency to create layers by adding time and place to communication. This, beyond being a search for support, is an effort to communicate in a sustainable manner.

\section{Campaign 4: Tortuga 1667: A Pirate Game of Mutiny, Plunder \& Deceit}

This campaign received 503 comments and the owner of the campaign made 4 updates. Within this framework, this is the campaign that has the most intense communication with its supporters

Campaign Advertisement Paper The year is 1667 and you are a pirate sailing the waters of the Caribbean. A Spanish Galleon floats nearby, and you've talked your crewmates into working together to steal all of its treasure. What you haven't told your fellow pirates is that you have no intentions on sharing the treasure once you have it. Your crewmates have told you that they share your loyalty and that they'll help you maroon the greedy pirates on your ship to the rocky island of Tortuga. But you've seen your friends' loaded pistols and heard their whisperings of a mutiny. You know that nobody can be trusted.

\section{Evaluation of the Communication:}

Storytelling model is used, and statements that will affect imagination of the audience and that will create a sense of belonging on the audience in the campaign advertisement paper. A sustainable chain of communication is provided by using visuals in the flow of communication.

Besides, the owner of the campaign shares the links of news and advertisement works about themselves on other social media and traditional media under the title of "Press". This forms a basis for transmediatic narration.

In the part of comment, the owner of the campaign answers the questions and suggestions of the supporters one by one. Therefore, a bilateral communication is provided.

Figure 1: Visual showing that the campaign received support from the $\mathbf{E U}$

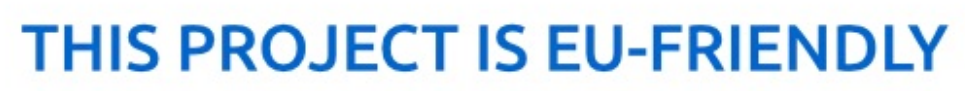

Rewards bound for the EU will ship from within the EU No extra customs charges!

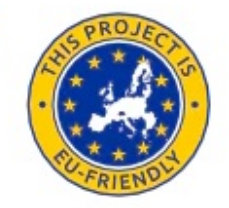


Figure 2: Visual regarding the content of the campaign

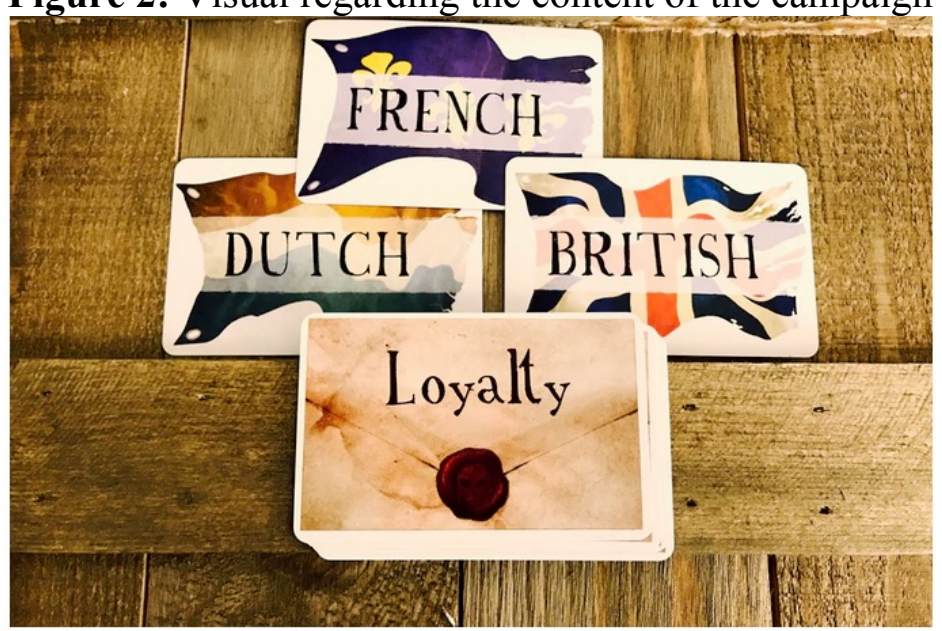

Each player has a secret loyalty: British, Dutch, or French. But be careful who you trust; someone claiming to share your loyalty may stab you in the back and steal your hard-earned treasure.

The owner of the campaign tries to reach to the audience with symbols and values by sharing this visual. The owner emphasises the honour and mystery of being English, French and Dutch, and sends messages to the subconscious of the audience by relating these identities with the concept of loyalty. This study which involves the most intensely conducted studies of communication received 505 comments.

\section{Campaign 5: Mini Museum 3: The Third Editio}

This campaign, which set out to raise 200.000 dollars, found 252 supporters from 12 different countries in a short time, and as a result raised 697.407 dollars. The owner declared that the campaign achieved 200.000 dollars in just five minutes by updating the campaign.

Campaign Advertisement Paper: My name is Hans Fex and I am the creator of the Mini Museum, the personal collection of curiosities from Earth and beyond! Since our first Kickstarter, we've shipped more than 10,000 Mini Museums all over the world. I am so grateful to all of our backers and we're excited to come back to Kickstarter to share the all-new Third Edition with everyone. So let's get started! A Mini Museum is a handcrafted, limited edition collectible, designed to inspire learning and exploration. Every specimen in the Mini Museum is authentic, iconic, and labeled. I've been collecting rare and fascinating objects for most of my life, ever since my father gave me my first specimens in 1977. Over the years, I've been fortunate to meet many amazing people including scientists, museum curators, astronauts, and other adventurers. With their help, I've been able to assemble an incredible collection which I am now sharing with the world.

Why kickstater? ackers of our first two projects know how strongly I believe in Kickstarter. The support of this community is what's made the Mini Museum possible and allowed me to fulfill my life long dream of sharing my love of science and history with the world.

\section{Evaluation of the Campaign:}

The owner tried to establish a warm communication with the audience by mentioning about characteristic features in the campaign advertisement paper. In addition, a new strategy was developed by using visuals and information in the advertisement paper. Symbols, rituals, values and both the product and the stories of the owner was revealed with the use of visuals.

Figure 3: Advertisement Process of the Campaign 


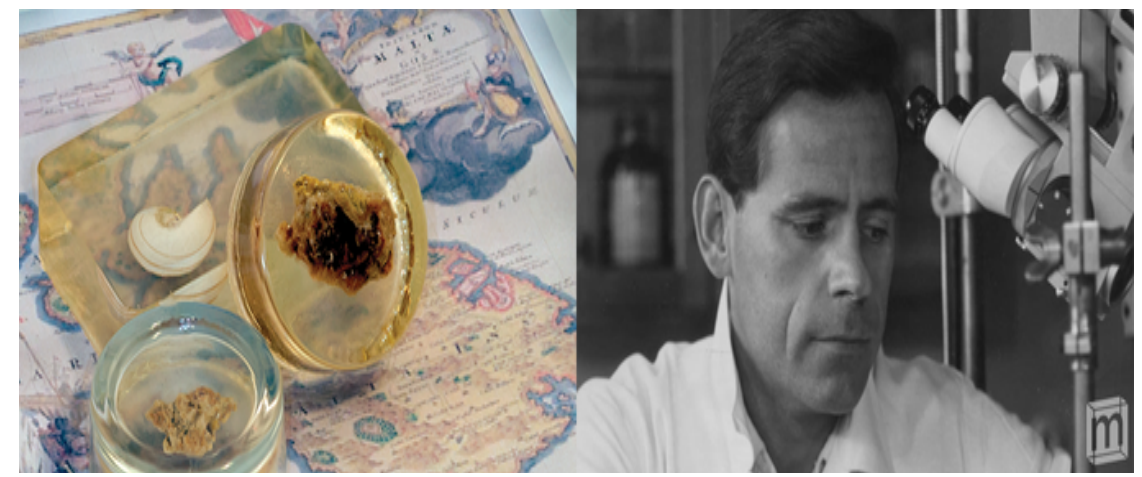

In this visual, the owner made his campaign and his story gain depth by referring to studies conducted by his father.

Figure 4: Advertisement Process of the Campaign

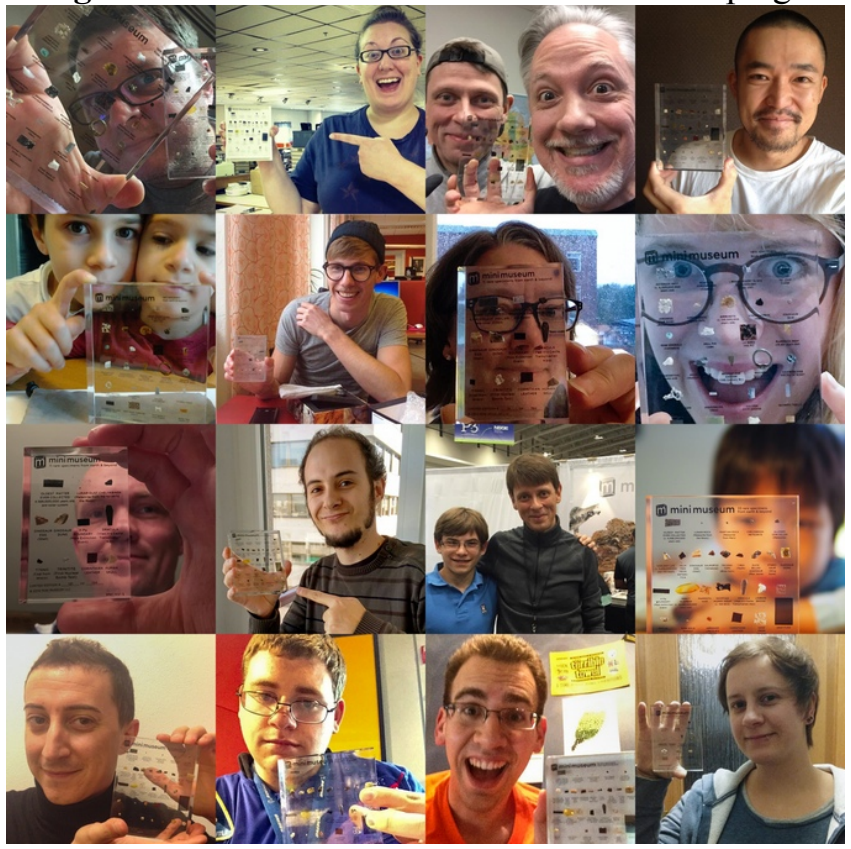

The owner of the campaign moved his supporters into this platform via visual in Figure 4. This gave the campaign the feature of transmediatic storytelling. In other words, different people from different layers supported the campaign. This is important in terms of sustainability of the communication.

In the "Comment" part of the campaign, the owner of the campaign replied to each and every one of the participants.

"Hi, folks! Helper Stephanie here. I thought I'd jump in this morning with a couple of points while Hans is still asleep in Arizona. :) Frankly, he deserves the sleep. Big flu going on out there and he got hit hard.

@ MichaelMTallman (and many, many others) - The Samurai Sword cross section is likely to show up as an addon, but the quantity will be extremely limited - even by our standards. The blade is only so long!

@ $\backslash[T] /$ SOLAIRE $\backslash[T] /$ - You won't be disappointed in the process update. The Samurai Sword specimen was just an incredible thing to witness in production.

@ Argail - The polish kit available in our shop will be available as an add-on during the post-campaign process. It can be used on any Mini Museum, though MM1 was made with a different material from MM2/MM3 so you'll want to be sure to read the instructions we send along carefully. If I recall, there was a good discussion about the difference on the MMI comment board. P.S. THANK YOU!

@Justin Tobin - The complete MM3 run hasn't been determined yet but it will probably be a little larger than MM1. It really depends on the number of 12 specimen versions that go in the Kickstarter here, and of course the very limited nature of the specimens. Hans is planning to release the size in a project update once we know.

If you have a question that we haven't answered, please feel free to reach out to us atservice@minimuseum.com!” 
While writing the replies, the owner wrote both solution oriented for the problems and messages of thanks to the supporters. In addition, he shared his mail address for more information and sharings. Therefore, the strategy of supporting bilateral communication was followed.

\section{CONCLUSION}

Online crowdfunding devices find a considerable amount of supporters from different areas of the world. This is the outcome of the studies of communication which are important both from the visual and verbal aspect. In this study, elements regarding the use of crowdfunding as a communication device in public relations are researched.

As a result of the literature review and field research, it can be seen that crowdfunding web pages are originated in America and they are gradually becoming popular in the Europe. A system that is used so much in different areas of the world occurred in a similar manner in different countries. However, they were not as successful as the American web pages. It is determined that the basis for this is problems in the countries regarding law and taxation. Especially in countries, in which works on legal infrastructure regarding internet applications are limited, these kind of applications are not very successful.

Online crowdfunding web pages can be considered as a means of public relations since, in those pages, communication between groups takes place, there is bilateral communication which benefits both sides, there are planned studies aiming to affect the audience with honest and liable applications. This supports the studies conducted by Bu da Hui et al (2014). Although crowdfunding web pages have become a means of public relations, these pages have brought about some problems. The owners of the campaigns and supporters in online crowdfunding web pages are intertwined. This raises difficulties in defining audience which is the basis for public relations. Therefore, handicaps are a matter of question when the audience and the owners of the campaigns are trying to know each other and communicate according to their expectations in online crowdfunding web pages.

As a result of netnographic and content analyses, effects of crowdfunding web pages on both creating a sustainable communication and creating a sustainable society have been determined. Both applications of sustainable communication and works of creating a sustainable society have been observerd especially in campaign-3, campaign-4 and campaign-5. Similarly, Sakamoto\& Nakajima (2013) determined in their studies that crowdfunding increases awareness in terms of social sustainability.

The most important public relations study in online crowdfunding web pages is studying content and studies aimed at marketing. The owners of the campaign creates stories about the campaigns and sometimes they transfer it to other social media platforms in order to find more supporters. Thus, transmedia storytelling narrations are created by creating a stratified structure in communication. However, it is determined in the field research that there are scarcely any transmedia applications.

When considered from the perspective of public relations, the most important problem is the lack of an understanding of a professional management of communication. Communication is maintained according to the guidance of supporters. In addition, it is always difficult to build up reputation and trust on the internet platforms. In particular, building up reputation and trust on these kind of funding applications is really difficult (Rubinton, 2011:5). The basis solution for this problem is to build a serious public relations strategy at the very beginning of the campaign. In particular, skills, reputation, symbols, rituals and values of the owner of the campaign should be integrated with the campaign, and corporate identity should be reconstructed. Because, carrying traditional corporate identity is difficult in online crowdfunding platforms, and corporations can be seen as a simple trade company by supporters. 


\section{REFERENCES}

Alfiero, S., Casalegno, C., Indelicato, A., Rainero, C., Secinaro, S., Tradori, V., \& Venuti, F. (2014). Communication as the Basis for a Sustainable Crowdfunding: The Italian Case. International Journal of Humanities and Social Science, 4(5), pp.46-55

Anderson, R., \& Reagan, J. (1992). Practitioner roles and uses of new technologies. Journalism Quarterly, 69, 156-165.

Belleflamme, P., Lambert, T., \& Schwienbacher, A. (2014). Crowdfunding: Tapping the right crowd. Journalof Business Venturing, 29(5), pp.585-609.

Colombo, M. G., Franzoni, C., \& Lamastra, C. (2015). Internal social capital and the attraction of early contributions in crowdfunding. Entrepreneurship Theory and Practice, 39(1), pp.75-100.

Cutlip, S. M. (2013). The unseen power: Public relations: A history. Routledge

De Buysere, K., Gajda, O., Kleverlaan, R., Marom, D., \& Klaes, M. (2012). A framework for European crowdfunding. European Crowdfunding Network.

Gerber, E. (2011). Innovation self-efficacy: Fostering beliefs in our ability through and by design. Core 77.

Gerber, E. M., \& Hui, J. (2013). Crowdfunding: Motivations and deterrents for participation. ACM Transactions on Computer-Human Interaction (TOCHI), 20(6), 34.

Granovetter, M.S. (1973). The Strength of Weak Ties. American Journal of Sociology (78), 6, pp.1360-1380

Güven, S. (2016a). Kurumsal İletişim Bağlaminda Kurumsal Sosyal Sorumluluk ve Etik Illişkisi, Akdeniz İletişim Dergisi, (26), pp. 133-154).

Güven, S. (2016b). Türkiye'de Siyasal Hayatta Dönüşüm ve Lider Odakll Siyaset, Selçuk İletişim Dergisi, 2016, 9 (3), pp.90-118.

Harlow, R. F. (1976). Building a public relations definition. Public Relations Review, 2(4), 34-42.

Holtz, S. (2002). Public relations on the Net: winning strategies to inform and influence the media, the investment community, the government, the public, and more!. Amacom Div American Mgmt Assn.

Hui, J. S., Gerber, E. M., \& Gergle, D. (2014, June). Understanding and leveraging social networks for crowdfunding: opportunities and challenges. In Proceedings of the 2014 conference on Designing interactive systems (pp. 677-680). ACM.

Hutton, J. G. (1999). The definition, dimensions, and domain of public relations. Public Relations Review, 25(2), 199-214.

Kozinets, R. V. (2002). The field behind the screen: Using netnography for marketing research in online communities. Journal of Marketing Research, 39(1), 61-72.

Kuşay, Y., \& Akbayır, Z. (2015). Dijital Oyunlar ile Tüketime Yolculuk:" Öğrenme Yaklaşımı Açısından Çocuk Kullanıcılara Yönelik Bir Araştırma. Akdeniz Iletişsim Dergisi, (23). 135-154

Lee, E. A., \& Messerschmitt, D. G. (2012). Digital Communication. Springer Science \& Business Media.

Long, L. W., \& Hazelton, V. (1987). Public relations: A theoretical and practical response. Public Relations Review, 13(2), 3-13.

Lu, C. T., Xie, S., Kong, X., \& Yu, P. S. (2014, February). Inferring the impacts of social media on crowdfunding. In Proceedings of the 7th ACM international conference on Web search and data mining (pp. 573-582). ACM.

Macht, S. A. (2014). Reaping Value-Added Benefits from Crowdfunders: What Can We Learn From Relationship Marketing? Strategic Change. 23(7-8), 439-460. doi:10.1002/jsc.1988

Macht, S. A., \& Weatherston, J. (2014). The Benefits of Online Crowdfunding for Fund Seeking Business Ventures. Strategic Change, 23(1-2), 1-14. doi:10.1002/jsc.1955

Muller, M., Geyer, W., Soule, T., Daniels, S., \& Cheng, L. T. (2013, April). Crowdfunding inside the enterprise: employee-initiatives for innovation and collaboration. In Proceedings of the SIGCHI conference on human factors in computing systems (pp. 503-512). ACM.

Peltekoğlu, Filiz (2015), Halkla İlişkiler Nedir?. Beta Yayınları:İstanbul

Pelenk Ö., A. \& Yılmaz S. (2015). Dijital Halkla İlişkiler, Kavram ve Araçları. Der

Yayinlart:İstanbul

Porter, L. V., Trammell, K. D. S., Chung, D., \& Kim, E. (2007). Blog power: Examining the effects of practitioner blog use on power in public relations. Public Relations Review, 33(1), 92-95.

Rubinton, B. J. (2011). Crowdfunding: disintermediated investment banking. 
Sakamoto, M., \& Nakajima, T. (2013, December). Micro-crowdfunding: achieving a sustainable society through economic and social incentives in micro-level crowdfunding. In Proceedings of the 12th International Conference on Mobile and Ubiquitous Multimedia (p. 29). ACM.

Seyfi, M., \& Güven, D. (2016) The Perception and Awareness Levels of University Students in Turkey Regarding Crisis Situations in Social Media: The University of Marmara Example, Athens Journal of Mass Media and Communications, 2 (4), 269-280

Seyfi, M., \& Soydaş, A. U. (2016). Socio-Spatial Segregations in Social Media. Fonseca, Journal of Communication, (13), 153-168.

Springston, J. K. (2001). Public Relations And New Media Technology: The impact of the Internet. In Robert Heath (Ed.), Public relations handbook (pp. 603-614). Newbury Park, CA: Sage

Vismara, S. (2016). Equity Retention and Social Network Theory in Equity Crowdfunding. Small Business Economics. 46 (4). doi:10.1007/s11187-016-9710-4

Wang, D. (2016) Corporate Crowdfunding As a Marketing Communication Tool, master thesis, Erasmus School of History, Culture and Communication Erasmus University Rotterdam

Wojciechowski, A. (2009, November). Models of charity donations and project funding in social networks. In OTM Confederated International Conferences" On the Move to Meaningful Internet Systems" (pp. 454-463). Springer Berlin Heidelberg

Xu, A., Yang, X., Rao, H., Fu, W. T., Huang, S. W., \& Bailey, B. P. (2014, April). Show me the money!: An analysis of project updates during crowdfunding campaigns. In Proceedings of the SIGCHI conference on human factors in computing systems (pp. 591-600). ACM.

www.kickstarter.com, 03.01.2017

http://www.crowd101.com/crowdfunding-ideas-to-steal-from-president-obama/), 12.12.2016 